\title{
14 Proverbs and Foreign Language Teaching
}

\subsection{Introduction}

This chapter intends to provide answers to the following questions: (1) Why should proverbs play a part in foreign language teaching? (2) Which proverbs should be taught and learnt? (3) How can the teaching of proverbs be best accomplished? At the same time, it will offer an overview of current issues in phraseodidactic research and will, in addition, attempt to compile a proverb minimum (or optimum) found in the appendix. The chapter draws on the results of a survey on the knowledge of proverbs conducted among advanced learners of English. It focuses specifically on English and German, but the ideas presented can easily be adapted to the teaching of other languages.

\subsection{Proverbs in Foreign Language Learning and Teaching}

\subsubsection{On the Significance of Including Proverbs into Foreign Language Teaching}

The task of foreign language teaching is to enable students to communicate in a language that is not their mother tongue. This means providing them with the most useful lexical and grammatical material and the necessary communicative strategies to apply their knowledge adequately. The characteristic features of language use in the target language should therefore form the point of departure. Research has established that phraseology is fundamental to the way language is used (Biber \& Conrad, 1999; Moon, 1998; Wray, 2002, 2008; Schmitt, 2004; Granger \& Meunier, 2008; Meunier \& Granger, 2008). Phraseology includes a set of fixed polylexemic linguistic units which are characterized by semantic and syntactic stability and to a great extent by idiomaticity (Fiedler, 2007: 28), such as formulae, phrasal verbs, proverbial sayings, similes, binomials, and proverbs. Proverbs are considered here to be a part of the phrasicon of a language, and a subtype of phraseology. Knowledge of them is necessary for native and non-native speakers of a language to communicate effectively.

Despite the pervasiveness of proverbs in oral and written communication there is no accepted consensus about their role in foreign language teaching. On the one hand, as the time that teachers have at their disposal in language classes is limited, it seems to be a sheer luxury to teach proverbs in a context in which the pronunciation of words and grammatical structures still causes problems. If the importance of phraseological units is acknowledged at all, it might be reasonable to prioritize subtypes 
such as collocations or phrasal verbs over proverbs, because these may constitute a serious problem for language production and have to be mastered as an active language skill. On the other hand, textlinguistic research and discourse analysis have revealed that proverbs realize a large number of referential, communicative and textual functions and that they are also used in academic discourse (Gläser, 1990). It is due to the progress in phraseodidactics and its interconnectedness with other disciplines that the majority of researchers today agree on including proverbs in foreign language teaching (e.g. Mieder, 2004d; Hallsteinsdóttir, 2011; Nuessel, 2003; Lennon, 1998; Baur \& Chlosta, 1996).

The important role that phraseology plays in communication, foreign language learning and teaching is also acknowledged by the Common European Framework of Reference for Languages (CEFR), which aims to provide a common basis for the development of curricula, teaching materials and levels of proficiency for foreign language learning in Europe. The knowledge and appropriate use of proverbs are considered to be a relevant part of a learner's lexical competence (5.2.1.1 of the CEFR) as well as a key factor for the development of pupils' sociolinguistic competence:

These fixed formulae, which both incorporate and reinforce common attitudes, make a significant contribution to popular culture. They are frequently used, or perhaps more often referred to or played upon, for instance in newspaper headlines. A knowledge of this accumulated folk wisdom, expressed in language assumed to be known to all, is a significant component of the linguistic aspect of sociocultural competence.

The following subgroups and examples of the so-called expression of folk wisdom are mentioned:

proverbs, e.g. a stitch in time saves nine

idioms, e.g. a sprat to catch a mackerel

familiar quotations, e.g. a man's a man for a' that

expressions of:

belief, such as - weathersaws, e.g. Fine before seven, rain by eleven

attitudes, such as - clichés, e.g. It takes all sorts to make a world

values, e.g. It's not cricket. (CEFR p. 120)

The English draft forms the basis of this important document and, strangely enough, the German translation tries to find examples that take the English ones as its means of orientation. In this way, Gleich getan, ist viel gespart - obviously a translation of the English A stitch in time saves nine, but unknown in German - is given as an example of a proverb, where a commonly used German proverb would have been expected. Other drawbacks of this document are the heterogeneous use of terms (for example, fixed phrase [p. 111], stock phrase [p. 35, 86], fixed formulae [p. 120], expression of folk wisdom [p. 120], frequently used 'routines' and patterns [p. 29] are used interchangeably to denote the same subject) and the fact that the CEFR does not address the question of which phraseological units (including proverbs) are to be taught on which 
levels, i.e., that it does not tackle the problem of a phraseological (and paremiological) minimum (Pirttisaari, 2006). Further phraseodidactic research will thus have to place particular emphasis on these aspects (Konecny et al., 2013). In the following we examine in more detail why proverbs should be taught and learnt, and identify motivational, linguistic, cultural and epistemological reasons.

\subsubsection{The Motivational Potential of Proverbs}

B. Wotjak (1996: 7) mentions the strong interest that learners have in proverbs. This can mainly be attributed to their colourful authenticity and the insight they provide into a language community's culture and history. In addition, proverbs are popular because of their stylistic features (e.g. alliteration, rhyme, rhythm, parallelism) (chapter 1 of this Handbook). Therefore, proverbs can present great motivational potential because students are challenged by being obliged to analyse their linguistic content and to understand their often figurative meaning in a given situational context. As the CEFR quote above indicates (and as chapter 15 about anti-proverbs in this book will show in more detail), proverbs are often modified or alluded to. Those creative uses, as language play in general, evokes humour and intellectual joy, which stimulates learners and helps to enliven lessons.

\subsubsection{Proverbs as a Basis for Language Learning and Teaching}

Proverbs are a ubiquitous phenomenon, an integral part of authentic language use. This seems to be especially true for the situations and genres that the major part of our language learners, school and university students, are faced with. Pop music is rich in proverbs (Mieder, 1989; Lenk, 2001); so are films (Winick, 2003); funny proverbs are used as status updates on Facebook, and manipulated proverbs are popular in genres of youth culture (e.g. T-shirt slogans, flyers, false logos). The inclusion of proverbs in the curriculum gives learners the chance to apply the linguistic knowledge they have acquired outside the classroom and offers teachers the opportunity to make their pupils familiar with vocabulary, grammatical patterns and phonetic rules on the basis of the material that is in the focus of their interests. One might call this the linguistic reason or the language competence argument. Proverbs are a substantial constituent of language overall and they illustrate important functions in discourse. Litovkina (2000: vii) argues as follows (see also Hanzén, 2007: 8-10):

The person who does not acquire competence in using proverbs will be limited in conversation, will have difficulty comprehending a wide variety of printed matter, radio television, songs etc., and will not understand proverb parodies which presuppose a familiarity with a stock proverb. Furthermore proverbs are ideally suited to pedagogical purposes because they are easy to learn 
(...) They contain frequently used vocabulary and exemplify the entire gamut of grammatical and syntactic structures.

A large number of researchers have argued in this direction and provided material for several languages taking proverbs and other types of phraseological units as a starting point for second language classes ${ }^{176}$ (e.g. Litovkina, 2000; Abadi, 2000; Wilson, 2004; Hessky \& Ettinger, 1997; Bardósi, Ettinger \& Stölting, 2003; Lattey \& Hieke, 1990; Nuessel, 1982; Wotjak \& Richter, 1988).

\subsubsection{Proverbs and Figurative Language}

Another factor that makes the significance of proverbs for foreign language teaching evident is its extensive reliance on figurative speech. The majority of proverbs are metaphorical or involve some kind of metaphor (Norrick, 1985). Examples are proverbs such as Too many cooks spoil the broth and Make hay while the sun shines. As Lakoff \& Johnson (1980: 5) put it, "the essence of metaphor is understanding and experiencing one kind of thing in terms of another”. Metaphors involve a transfer from one (usually relatively concrete) cognitive domain to another (typically more abstract one) based on a relationship of similarity or analogy. They enable us to describe the world because we grasp new concepts with the help of already existing categories. This "epistemological function of metaphor" (Nuessel, 2003: 402) is central to our cognitive development. Proverbs can also be metonymic as they are based on an objectively existing relationship between two entities. In Two heads are better than one and Absence makes the heart grow fonder, for example, the two parts of the human body are used on the basis of a pars pro toto relationship. Both metaphor and metonymy are important because they fulfil crucial functions in discourse. The metaphors and metonymies we find in proverbs are not freely created, but prefabricated. The decoding processes, however, are similar. Therefore, the inclusion of proverbs and the discussion of their nature in foreign language learning can help students to develop the ability to further understand figurative language.

\subsubsection{Proverbs as a Mirror of Culture}

Proverbs provide insight into culture in a number of ways. As they are inherited from generation to generation they preserve traditional (and sometimes outdated) views and values, behaviour, experiences, and working methods (e.g. Early to bed and early to rise, makes a man healthy, wealthy, and wise; Spare the rod and spoil the child; $A$

176 The terms second language, foreign language, and L2 are used synonymously in this chapter. 
woman's place is in the home). Simultaneously, modern proverbs (e.g. What you see is what you get; Garbage in, garbage out; $A$ woman without a man is like a fish without a bicycle) reflect life in the age of computers as well as the changing position of women in society. In addition, culture-boundedness can be seen in the positive or negative connotations of particular proverbial elements. For example, dog is mainly used in a derogatory sense in English (e.g. Every dog has its day) and heart is commonly considered the seat of feelings (e.g. Absence makes the heart grow fonder).

Proverbs not only give insight into former ways of thinking, judging and working, but some of them also provide insights into previous stages of a language. Examples in English are He who hesitates is lost and Manners maketh the man. In this way, the incorporation of proverbs creates a tremendous opportunity to integrate literary-cultural with linguistic education (Awramiuk, 2011).

The idea that proverbs reflect the culture of a speech community does not mean, however, that there is a 1:1-relation between the content of proverbs and the worldview of a nation. As Mieder (2007: 402) argues, "[c]are must be taken when looking at proverbs as expressing aspects of a certain worldview or mentality of a people that no stereotypical conclusions about a so-called 'national character' are drawn."

In fact, proverbs often contain national stereotypes and racial prejudice and their potential as disseminators of those views should not be underestimated. As Mieder (1993) shows, the proverb-like formula Only a dead Indian is a good Indian not only served as a defamatory slogan about native Americans, but became a productive model for slurs against other ethnic groups. It is, however, questionable whether this is a reason to ignore them. They should instead be addressed and challenged within the language curriculum as proverbs that include stereotypes have potential in terms of character-education. Their appropriate treatment in the language classroom can help raise awareness and cultivate an open and critical mind (Popovic, 2004).

A cultural perspective on proverbs should also include their use. It has been widely acknowledged that there are a number of culture-bound differences and peculiarities with regard to this. For example, in China proverbs are more often used than in other countries, and signal an author's high level of education and experience (You Ting, 2010: 151; Günthner, 1990), which is why they permeate even academic works. Such cultural differences and traditions have to be taken into consideration in foreign language teaching. As regards English, the dominance of this language as a means of international communication should be born in mind. The use of a foreign language is not restricted to the application of vocabulary and grammar, as textual conventions and rhetorical traditions that exist in the speech community are of importance as well. As contrastive discourse analyses have revealed, metaphor plays a central role in English academic prose (Thielmann, 2009), and humorous introductions are characteristic for scientific presentations (Reershemius, 2012). Proverbs can play an important part in the realisation of both these textual functions and should be considered in this context at least in advanced stages of foreign language classes. 


\subsubsection{Proverbs and Fluency}

As mentioned before, phraseology (including proverbs) is a substantial constituent of language. Data about their proportion in communication vary and depend on register and genre. Erman and Warren (2000) found that as much as 58.6\% of spoken discourse and $52.3 \%$ of written language was prefabricated. Howarth (1998) in his study on academic writing found that between 31 and 40\% was made up of phraseological units (collocations and idioms). Phraseology serves to facilitate language use by providing a processing advantage and as a number of studies have revealed, the use of prefabricated phrases and sentences decreases processing efforts in speech production and improve learners' fluency (e.g. Wray, 2002; Conklin \& Schmitt, 2008). Pawley \& Snyder (1983: 208), introducing the term institutionalized sentence stem for holistically stored sequences, were among the first to describe this:

Indeed, we believe that memorized sentences and phrases are the normal building blocks of fluent spoken discourse, and at the same time, that they provide models for the creation of many (partly) new sequences which are memorable and in their turn enter the stock of familiar usages.

Their list of examples includes a number of proverbs, such as You can lead a horse to water, but you can't make it drink; A stitch in time saves nine; Think twice before you +verb phrase [e.g. leap]). Their knowledge is advantageous to foreign language learners both in receptive and productive language use. It aids comprehension because it makes the incoming language flow predictive, and eases processing loads in speech production as the speaker is able to concentrate on passages which are produced creatively (Lennon, 1998: 18).

\subsection{Towards a Proverb Optimum}

\subsubsection{Selection Criteria}

In foreign language instruction it is important to teach the most well-known and current material. This is true for both simple or complex word lexemes and for sentence-like expressions such as proverbs. "It is the proverbs that are in use today that ought to be taught," writes Mieder (2004d: 147). Therefore, it is of utmost importance to find the current and most frequently used proverbs as a base for teaching.

According to Grzybek \& Chlosta (2009), studies aimed at compiling a paremiological minimum can be subdivided into frequency-oriented approaches, which are based on the analysis of written and spoken texts, and knowledge-oriented methods, which are based on testing a particular number of subjects. Corpora, which are now generally used in language studies in order to check theoretical hypotheses, provide 
problems for phraseologists and paremiologists. A number of studies conducted for several languages have shown that the average frequency of well-known phraseological units including proverbs, is very low in corpora (Moon, 1998, Colson, 2007). "[T]here are often wide discrepancies between implicit native-speaker knowledge of idioms, catchphrases, proverbs and other word-combinations and their frequency of occurrence in large-scale computer corpora" (Cowie, 2003: 73). Corpus analysis can therefore not be the only method for finding a proverb optimum for foreign language learners. One of the first paremiologists to conduct research with regard to the second approach was G.L. Permiakov (1982, 1985), who published a list of 300 commonly used Russian proverbs. So-called paremiological minima (or proverb minima) have meanwhile been established for several languages (Čermák, 2003; Ďurčo, 2004; Hessky \& Ettinger, 1997; Kacjan, 2013).

With regard to the English language, a precise proverb minimum is still a desideratum. However, a number of researchers have done important preparatory work in this field. Litovkina's (2000) book includes exercises to practise and apply 450 Anglo-American proverbs. Mieder (2004d: 129f.) presents a list of 75 proverbs that "are certainly used with high frequency in the United States". Lau's (1996) study on US-proverbs and their relation to American values includes a list of 188 American proverbs with their number of occurrences in Lexis/Nexi, a corpus of US and overseas newspapers, magazines and journals. On the basis of empirical research (proverb generation tasks and proverb familiarity tests with college students in four regions of the USA), Haas (2008) presents a list of 313 commonly known and used English proverbs. Using these collections in combination with the author's own proverb collection (Fiedler 2007: 90) ${ }^{177}$ and the Collins COBUILD Idioms Dictionary (2002) ${ }^{178}$ as sources, a list of 100 commonly used English proverbs has been compiled (see Appendix 1).

A decisive factor for the inclusion of a proverb into this list was its use in a 'marked' or innovative way (Fiedler, 2007). Those marked uses include different types of modifications of proverbs (exchange, reordering or addition of constituents), the creation of deliberate ambiguity (of phraseological puns - Naciscione, 2010), combinations of proverbs (or accumulation - Partington, 2009: 1808), their overuse, nonverbal presentation and other techniques. These uses are a type of ludic linguistic behaviour or language play (Crystal, 1998). The following newspaper headlines and text passages illustrate this:

177 The author's corpus has been built up primarily during a period of 25 years of intensive but unsystematic collecting of items from newspapers, literary and academic texts, conversation, television and radio programmes.

178 This dictionary is based on the Bank of English corpus comprising over 450 million words. It covers both British and American phraseology and includes labels for the most frequent phraseological units. 
Hillary, not curiosity, killed the cat ${ }^{179}$

Why writers want to swap pens for swords ${ }^{180}$

The sequester chickens have come home to roost or they would have if they could get clearance to take off. ${ }^{181}$

The use of a proverb in such a marked way (as well as the existence of so-called antiproverbs - see chapter 15) can be considered proof of its currency. The authors presuppose that the reader/listener detects the phraseological base form, i.e. the proverb in its ordinary form (Naciscione, 2010: 47). Otherwise the intended effect would not be brought about. For all the 100 proverbs listed in the appendix, marked uses have been found.

The 100 expressions presented in Appendix 1 fulfil the following conditions for items in a paremiological minimum: Firstly, they correspond to the definition of proverbs presented in chapter 1 of this Handbook; ${ }^{182}$ secondly, they are familiar to and widely used by native speakers (Haas, 2008; column 4); thirdly, they are considered to be relevant to the English language and culture, according to the research of leading paremiologists (e.g. Mieder, 2004d; Litovkina, 2000; column 2); fourthly, they occur relatively frequently in corpora (CCID, column 5); and finally, they are used in the media (Lau, 1996; columns 3 and 6). The 100 items therefore present the proverbs a user of English is likely to encounter in oral and written communication, so that it will be useful for a learner of this language to know them and their meaning, at least in terms of receptive use. The question of whether the 100 proverbs presented in Appendix 1 constitute an individual learner's paremiological optimum is difficult to answer as it depends on a large number of factors, such as age, personality, learning context, native language, degree of language proficiency, purpose of learning the foreign language and others.

179 Sunday Independent (11 November 2007) (Hillary Clinton was accused of having killed a cat 180 Irish Independent (10 November 2007) (article on the strike launched by the Writers' Guild of America)

181 The Colbert Report (23 April 2013) (Flights were cancelled and delayed in the USA due to budget cuts, called the Sequester)

182 Some of the items in the various lists had to be excluded, as they represent other subtypes of phraseological units, such as binomials (e.g. penny-wise and pound-foolish in Mieder's list), catchphrases (e.g. Life is like a box of chocolates ... in Haas's list), and phrasal idioms (e.g. kill two birds with one stone in Haas's list). 


\subsubsection{A Questionnaire Study}

\subsubsection{The Knowledge of Proverbs Among Advanced Learners of English}

Due to their metaphorical contents and connotations proverbs are problematic for even fluent language learners. We have acquired the phraseological competence in our native language over the course of many years as a result of immersion in the cultural context in which the language is rooted (Prodromou, 2007: 23), and it is hardly possible to gain this competence in a foreign language.

To gain further insight into the state of knowledge of phraseology and especially proverbs and to find how their acquisition can be improved a survey among German university students of English was conducted (160 respondents; level of proficiency: $\mathrm{B} 2 / \mathrm{C} 1)$. In the first part of the questionnaire students were asked to paraphrase the meaning of eight English proverbs and, if possible, to note where or how they had learnt them. From these, four were presented non-verbally and had to be identified first from caricatures and a photograph (see appendix 2), which is cognitively and linguistically challenging for language learners. The results of this first part of the survey are presented in Table 14.1.

As Table 14.1 shows, the knowledge of the eight English proverbs - which are all considered to be part of the proverb minimum for English - was relatively poor. Only two of them (I The early bird catches the worm and III An apple a day keeps the doctor away) were known by the majority of students. Two proverbs (IV Waste not, want not and VIII The chickens come home to roost) were known by only 4 and $2 \mathrm{stu}$ dents respectively.

Those students who had spent a period of at least one term in an English-speaking country achieved better results, as in 4 out of the 8 proverbs they scored higher. As expected, older students knew more proverbs than younger ones. However, for the knowledge of some of the proverbs the year of studying does not seem to be as influential as a stay abroad.

The majority of respondents were not able to indicate where and how they had learnt a particular proverb, but those who provided information on this gave the following situations as sources: media (television/films/Internet/pop songs; 11 respondents), friends (e.g. "A friend told me about a couple of things that happened and ended: that was the last straw"/"my host mother in the UK always said so"; 9 respondents), linguistics seminar (7 r.), literature (e.g. "read it in a book"; 7 r.), school (4 r.), and family (4 r.). 
Table 14.1: Correct paraphrases (\%) of proverbs (presented in the given form [V-VIII] or in pictures Appendix $2-[\mathrm{I}-\mathrm{IV}])$

\begin{tabular}{|c|c|c|c|c|}
\hline & Proverb & $\begin{array}{l}\text { all students } \\
(=160)\end{array}$ & $\begin{array}{l}\text { students having } \\
\text { been abroad }^{183} \\
(=48)\end{array}$ & $\begin{array}{l}\text { students in } \\
\text { year } 3 \text { and } \\
\text { above }(=47)\end{array}$ \\
\hline 1 & The early bird catches the worm & 85.15 & 91.8 & 81.45 \\
\hline II & The pen is mightier than the sword & 11.7 & 6.7 & 6.3 \\
\hline III & $\begin{array}{l}\text { An apple a day keeps the doctor } \\
\text { away }\end{array}$ & 64.8 & 70.8 & 66.6 \\
\hline IV & Waste not, want not & 2.5 & 0 & 5.9 \\
\hline V & A stitch in time saves nine & 37.0 & 33.3 & 41.2 \\
\hline VI & The last straw ${ }^{184}$ & 11.1 & 16.8 & 22.6 \\
\hline VII & $\begin{array}{l}\text { Absence makes the heart grow } \\
\text { fonder }\end{array}$ & 44.4 & 66.7 & 58.8 \\
\hline VIII & The chickens come home to roost & 1.25 & 0 & 2.6 \\
\hline
\end{tabular}

\subsubsection{Mother Tongue Influences}

Irujo (1986) found that advanced learners of English rely on their first language to comprehend and produce second language idioms. The survey confirms these finding for the apprehension of proverbs. It reveals that L1 transfer plays an important role in learners' processing of L2 proverbs and that this transfer can be positive and negative. The two best known proverbs are I and III, which can be attributed to the fact that, due to the impact of English, both are well known as German proverbs as well. Der frühe Vogel fängt den Wurm is the popular German loan translation of the English proverb The early bird catches the worm (Mieder 2004a); An apple a day keeps the doctor away can be found in various German translations (Fiedler 2012a: 75) as well as in the English original (Mieder 2004c).

Negative transfer can be seen in the relatively large number of wrong answers for some of the little known proverbs. For the last straw, for example, no less than $45.1 \%$ of the paraphrases given were wrong, comprising "the last chance / hope / possibility / the only help / the only thing that helps / if nothing else works / the last thing you can cling to”. Obviously, they go back to the German literal counterpart der letzte

183 Including stays for at least 6 months.

184 This word-group unit was included because it is a short version of the proverb The last straw breaks the camel's back (Mieder et al., 1992: 567). 
Strohhalm (an den man sich klammert) (with the meaning 'to clutch at any straw'), which might be called a false friend.

\subsubsection{The Role of Context}

The second part of the survey referred to the role that context can play when proverbs are processed. The relatively little known proverbs II, IV, and V-VIII were now once more presented embedded in authentic texts (see Appendix 2). The survey reveals that the students, who again were asked to paraphrase the meaning of the proverbs, scored significantly higher in this part (see Table 14.2 and Figure 14.1).

Table 14.2: Correct paraphrases (\%) for proverbs embedded in texts

\begin{tabular}{llll}
\hline & Proverb & $\begin{array}{l}\text { Results } \\
\text { (context-isolated) }\end{array}$ & $\begin{array}{l}\text { Results } \\
\text { (embedded) }\end{array}$ \\
\hline II & The pen is mightier than the sword & 11.7 & 74.1 \\
\hline IV & Waste not, want not & 2.5 & 39.6 \\
\hline V & A stitch in time saves nine & 37.0 & 77.6 \\
\hline VI & The last straw & 11.1 & 42.6 \\
\hline VII & Absence makes the heart grow fonder & 44.4 & 84.5 \\
\hline VIII & The chickens come home to roost & 1.25 & 30.9 \\
\hline
\end{tabular}

The use of context (to be understood here as the immediate co-text, the words and phrases used together with the proverb) can be seen as a strategy to arrive at the meaning of an unknown unit (Cooper, 1999). This is obvious especially in the case of the proverb The pen is mightier than the sword. The high score for this proverb can be attributed to its self-explicatory character and its use in a report that illustrates it (see Appendix 2). The explicit phrase to reduce violence in America that is used in connection with the proverb will have been understood by all students. Even in the case of a little known and opaque proverb, the chickens come home to roost, a suitable context made more than a quarter of the students infer the correct meaning.

Nevertheless, context should not be overestimated. In none of the examples was it possible to reach a $100 \%$ score for an embedded proverb. Reasons for this might be that students were not able to understand all lexical items in the given texts or that they lacked the socio-cultural background knowledge to interpret the textual situation adequately. 


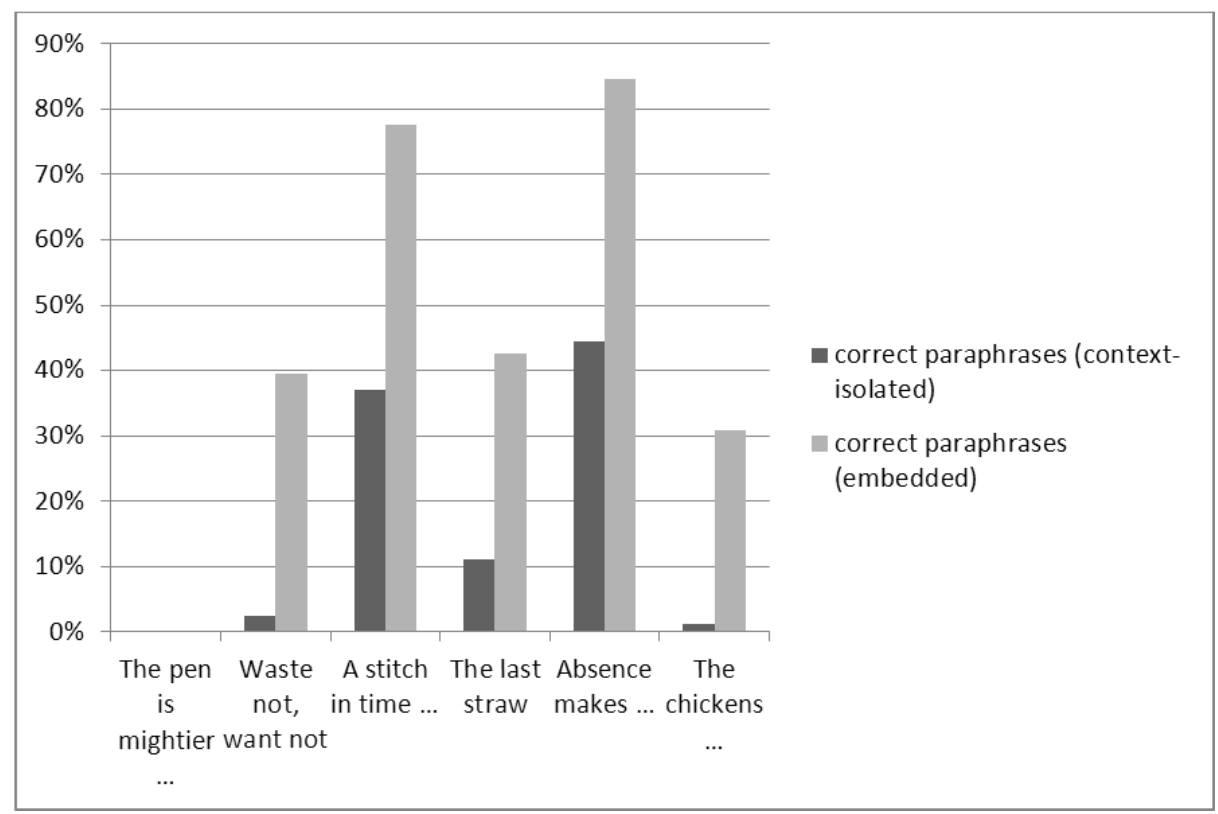

Figure 14.1: Correct paraphrases (context-isolated and embedded)

\subsubsection{Some Implications for the Learning and Teaching of Proverbs}

The questionnaire study presented in 3.2. threw some light on the knowledge of proverbs among advanced learners of English and on the way they processed them. Despite the limited number of participants and the relatively small number of proverbs tested the survey leads us to valid conclusions regarding the teaching of proverbs.

\subsubsection{Teaching Proverbs in an Appropriate Context}

One of the main results of the questionnaire study is that the meaning of proverbs is best apprehended in actual contexts of use. Proverbs need to be acquired in living performance (Mechling, 2004: 122). As Mieder (1996: 597) points out, “[p]roverbs in collections are almost meaningless or dead.” They refer to social situations and can be seen as strategies for dealing with them. For this reason, we should not divorce them from their contexts. Corpora enable us to provide suitable contexts. An example is given in appendix 2, where The chickens come home to roost is used in an authentic context, a spoken radio commentary. The socio-cultural background knowledge is easily activated by means of Internet sources (Wikipedia Moscow theatre hostage crisis, July1, 2013). More recent examples include the austerity program introduced in 
the USA in March 2013 known as Sequester. When it led to a number of problems in the economy, several newspapers made use of the proverb in their reports (3.1).

Students' analyses of those texts can form an ideal starting point in advanced language classes. As Nuessel (2003: 399) argues, "[t]he real linguistic task starts when the language learner attempts to learn when and how to apply the proverb to a concrete communicative situation". As the examples above show, modified proverbs should not be excluded from teaching materials and they give a good impression of the creative use of proverbs in present-day media.

The insight that proverbs and phraseology should be taught and acquired on the basis of authentic texts is very much in line with the three-step teaching model for phraseology in general ("phraseologischer Dreischritt") which was introduced by Kühn (1992). The first step ("Erkennen") is the identification of the proverb in a text. Learners have to be enabled to realise that a string of words is meant in a figurative sense. The second step ("Entschlüsseln"), the decoding process, includes that learners understand the meaning of a unit, which should therefore be presented in a typical context and genre. The third step ("Gebrauchen") is the use of a phrase or proverb. Lüger (1997: 98f.) proposes an extention of the model with a fourth step between steps two and three, which aims at consolidation: The use of a unit should be prepared and facilitated by suitable exercises.

The phase of identifying proverbs will be facilitated by students' knowledge of the formal characteristics of proverbs (such as rhyme, rhythm, formulaic pattern chapter 1 of this Handbook) and their metaphorical contents. The sentences Don't count your chickens before they are hatched and Make hay while the sun shines cannot be interpreted as ordinary propositions referring to animals or farming. As we have seen in the survey, metaphorical proverbs possess various degrees of transparency, and the existence of an equivalent in one's mother tongue can be important. In general, with regard to English, the identification of proverbs is not likely to cause severe problems. In the survey described above a considerable number of students were able to mark a proverb as something well-known, but they were not able to give its meaning (e.g. "I have heard it in pop songs, but I don't know what it means" for Absence makes the heart grow fonder). The dominant role of English in popular culture might be the reason why people are to a certain extent familiar with a number of proverbs and phrases in this language without really understanding or knowing them.

\subsubsection{Sources of Reference}

In order to understand proverbs, special dictionaries that are based on word usage in corpora have proven to be very helpful, as they contain examples excerpted from the corpora, like the Collins Cobuild Idiom Dictionary. As proverbs do not occur frequently in corpora (3.1.), however, not all of those that are considered as belonging to the paremiological minimum can be found in dictionaries. For example, Waste not, want not (known by only $2.3 \%$ of the respondents in our survey) is not included in the CCID. 
In cases like these on-line resources can be recommended, such as, for English, The Phrase Finder (www.phrases.uk.com). Here a query about Waste not, want not results in the following information:

Waste not...

Posted by ESC on May 10, 2000

In Reply to: Phrase posted by sherri novak on May 09, 2000

: Where and when and by whom did the phrase "waste not want not" start?

"Waste not, want not. The less we waste, the less we lack in the future. The proverb has been traced back to 1772, and is first cited in the United States in the 1932 'Topper Takes a Trip' by T. Smith...” From the "Random House Dictionary of Popular Proverbs and Sayings" by Gregory Y. Titelman (Random House, New York, 1996).

Re: Waste not... ESC 05/10/00

"A Dictionary of American Proverbs" by Wolfgang Mieder \& others (Oxford University Press, New York, 1992) cites the 1932 use of the phrase. It also has "1. Those who waste will want. (recorded distribution) [...]"

In addition, students can be encouraged to join forums for debate on phraseology. As the following passages show, in the case of Waste not, want not this turns out to be helpful, as the information given by users includes synonyms for some of the words as well as on the structure of the proverb:

\section{What exactly does the term "waste not want not" mean?}

CLIVE H: The term "waste not want not" probably originates in Yorkshire and means exactly what it says, never wasting anything results in never wanting anything.[...]

D_r_siva: [...] If we don't waste what we have, we'll still have it in the future and will not lack (want) it.

Snowflake...: If you waste stuff, later on you will find yourself without stuff and therefore "want”. So if you don't waste, you are conservative and won't want things later. I don't see how it relates to food, though.

Mandy_01: If you don't waste what you have now, you won't be in want (needy, lacking, poor) later.

Maxwell: If you don't waste food then you'll have less reason to want it later. I personally think 'waste not, need not' is more effective.

Kevin: It means if you don't waste things, you will never lack (want) for things that you need.

Merlin: it means If you don't waste things, you are less likely to end up lacking. (http://de.answers.yahoo.com/question/index?qid=20081121140038AAMLiQ6, July1, 2013) 


\subsubsection{Receptive and Productive Knowledge}

Kühn's third step, Use or Application, leads us to the principal question of whether the productive use of proverbs should be considered an aim of foreign language teaching at all. Several authors have expressed their hesitancy towards it because it might be seen as an inappropriate penetration into the native speaker's domain (Dobrovol'skij \& Ljubimova, 1993, Lüger, 2004: 158). O’Keeffe et al. (2007: 80) mention the "status as the 'badge of membership' of the speech communities from which they spring" that idioms have "because of their cultural resonance". This is certainly true for proverbs as well with their long traditions and cultural roots and so their use might be interpreted as an excessive identification with the target language community.

With regard to the productive use of proverbs, language learners' aims have to be taken into consideration. For those who have the desire to become members of the native-speaker culture, the productive use of frequent proverbs can be important. It will enable new immigrants to communicate effectively with Anglo-American native speakers, as Mieder (1994: 312) argues. Proverbs are often used to establish and solidify relationships, create humour and to confront problems in communities of practice (Wenger, 1998). The shared knowledge of a proverb can help to achieve interpersonal harmony between speakers.

For the majority of foreign language learners, however, the principle will be that "receptive mastery is more important than productive repertoire" (O'Keeffe et al., 2007: 76; see also Baur \& Chlosta, 1996: 23; Lüger, 2004: 157; Ettinger, 2007). As explained in 3.2.1., phraseological units including proverbs are stumbling blocks for non-native speakers. Prodromou (2007) has shown that non-native speakers are often not granted the same rights concerning the use of phraseology as native speakers. What is seen as creative play in native speaker conversations is often regarded as an error in non-native speakers' talk. The specialist literature includes more than a few examples of stylistic blunders with sayings and proverbs (e.g. Wotjak, 1996). They are probably what the authors of the CEFR had in mind when they described the "sociolinguistic appropriateness" of a B2-level speaker in the following way: "Can sustain relationships with native speakers without unintentionally amusing or irritating them or requiring them to behave other than they would with a native speaker." (Wotjak, 1996: 123)

Against the background of this field of tension - that, on the one hand, nonnative speakers want to be expressive and creative though using a foreign language and, on the other hand, the observation that the use of phraseology often presents a minefield - the strategy of metacommunicative signalling is worthwhile considering. Proverbs are often accompanied by expressions such as so to speak, as the proverb goes, as they say or we say. In this way speakers control and support the receiver's comprehension by marking their linguistic choices as something special, something that cannot be understood literally (Fiedler, 2007: 87-89; Čermák, 2004). Compare the following examples: 
The grass is always greener over here.

"The grass is always greener on the other side", as the old saying goes. But here in Ireland it happens to be true. We've definitely got green grass. At least 40 shades of it. (Leipziger Volkszeitung 4/5 December 1999)

One more big payday with Petty and that would be it for me. I was what they call over the hill. (B. Dylon Chronicles, 2004: 148)

Metacommunicative signals like these are highly recommended in intercultural communication, when the speaker is not sure of the stylistic adequacy of a proverb (Dobrovol'skij \& Ljubimova, 1993). Students have to be made aware of the fact that an additional cultural hedge such as, as you might say in English or isn't this a situation where you say ... can avoid embarrassment and unwelcome reactions.

\subsubsection{The Contrastive Perspective}

Phraseological equivalence presents an intensively studied field (Korhonen, 2007; Dobrovol'skij, 2011), and a number of authors have recently stressed the complexity of the issue by outlining different approaches of contrastive idiom research (Farø, 2006; Menado-Blanco, 2010). The present chapter of this handbook does not focus on equivalence as an abstract property used to describe the aimed-at quality of a target text in the translation (Koller, 2004), but instead is concerned with the existence of equivalents, i.e. of proverbs that can be regarded as identical or at least corresponding, and which serve as substitutes in two languages. The contrastive perspective is helpful in making students aware of the similarities and differences that exist between proverbs in a foreign language and their mother tongue.

Altogether four types of correspondence between L1 and L2 proverbs can be distinguished: Total equivalence, partial equivalence, zero-equivalence and pseudoequivalence. The reason for the existence of corresponding proverbs can be found in language contact and common sources. Examples of the former can be easily found due to the growing influence of English on European languages (Mieder, 2004a-c, 2010; Fiedler, 2006, 2010, 2012b; Rozumko, 2012b). With regard to common sources, identical or similar proverbs can be traced back to mythological stories, classical literary works (e.g., Shakespeare, Dante, Cervantes), folk narrations, fables and legends (Piirainen, 2010: 12; 2012). Among those internationally known loan translations are One hand washes the other, One swallow does not make a summer and All's well that ends well. Equivalents are not restricted to European languages, however. Paczolay's 1997 work registers equivalents of Like father, like son and Walls have ears in 46 languages each, including Chinese and Japanese and Arabic, Persian, Chinese, and Japanese respectively.

Taking the 100 English proverbs in Appendix 1 as a basis, equivalents for more than $40 \%$ can be found for German. However, as the inverted commas with the word total above serve to indicate, full equivalence, i.e. total correspondence in all possible parameters, does not seem realistic in two languages. As a number of researchers have 
convincingly shown (e.g. Gehweiler, 2006; Dobrovol'skij, 2002), superficially equivalent phraseological units, including proverbs, can differ with respect to frequency and register, and can have different variants and prefer different external arguments.

The group of partial equivalents encompasses proverbs with minor structural and/or lexical differences. The biblical warning "Pride goeth before destruction, and a haughty spirit before a fall" (Proverbs 16: 18) is known with the indefinite or definite article in English (Pride comes before a fall) and only with the definite article in German (Hochmut kommt vor dem Fall). The English proverbs $A$ bird in the hand is worth two in the bush is known in German with the same imagery basis, but different constituents, as Lieber den Spatz in der Hand als die Taube auf dem Dach [ww: Better a sparrow in the hand than a pigeon on the roof]. For the foreign language learner and user those minor grammatical and lexical differences can cause central problems as structural stability can be a decisive precondition of the proverbial character of an expression.

A further constellation is the lack of equivalents, i.e. the situation that a proverb in one language has no correspondent proverb in the other. For example, the English Every dog has its day has no counterpart in German. As mentioned above, in a situation where one language exercises dominant influence on other languages such a constellation is often a starting point for loan processes.

Finally, there is the occurrence of pseudo-equivalents, which are normally termed false friends (faux amis). They have identical constituents and are based on the same image, but carry different meanings. In the questionnaire study the last straw turned out to be one for the students. The complete proverb The last straw breaks the camel's back, which is rarely used today, would certainly not have caused problems. The popular reduction the last straw, however, made the participants remember the German expression with identical constituents, der letzte Strohhalm, which is a false friend (see 3.2.2.).

Students should know about these different types of equivalents to be alert to potential pitfalls. Here again it is on the level of the text that subtle differences become obvious and should be discussed. From a pragmatic point of view, the knowledge of equivalents and proverb parallels seems to be especially important, as their use might be a way for non-native speakers to be expressive and creative without entering the social space of another speech community or merely aping native speakers. It can be very useful for learners to know about the existence and correct wording of a proverb that they know from their native language and are therefore able to use adequately in the foreign language (Vajičková, 2000). In combination with the metacommunicative techniques described above (There is a proverb in my language ...) this might be a strategy to use colourful language, bring one's own culture and identity into the discourse and create a cooperative atmosphere by finding something that people have in common. The learner's individual proverb optimum should include some of those expressions, although they do not necessarily constitute the proverb minimum 
described above. For the two languages this chapter is focused on, this means that the following English proverbs are useful to know for German learners:

Constant dropping wears away the stone (German: Steter Tropfen höhlt den Stein) A burnt child dreads the fire (German: Ein gebranntes Kind scheut das Feuer) The apple doesn't fall far from the tree (German: Der Apfel fällt nicht weit vom Stamm) In wine is truth (German: Im Wein ist Wahrheit)

Coming events cast their shadows before (German: Große Ereignisse werfen ihre Schatten voraus).

An important aim of foreign language teaching is to enable students to continue their acquisition as part of their individual studies. As phraseological units and proverbs are ubiquitous phenomena, as we said in 1.1., they present an ideal subject for autonomous learning. Students should be encouraged to keep notebooks containing proverbs that they encounter outside the classroom (Irujo, 1993: 217) or to use worksheets, models of which Ettinger (2001) and Lüger (2004) prepared for French. In addition, several researchers (e.g. Ettinger, 2001; Bergerová [no year]) show didactic perspectives in combination with modern media (web-concordancer, Internet, CD-ROM) (see also Konecny et al., 2013).

\subsection{Final Remarks}

The findings to emerge from this study can be summarized in the following theses:

- Proverbs should be incorporated into foreign language teaching as they present a ubiquitous phenomenon that the learner encounters in authentic communication. In addition, the inclusion of proverbs motivates learners, helps to develop the ability of understanding figurative language, provides an insight into foreign cultures and supports natural and fluent communication by providing a processing advantage.

- Proverbs should be taught and learnt in context under consideration of their multiple functions in various text types of oral and written communication.

- Students should be taught those proverbs that they are likely to find in authentic communication. A collection of the most frequently used proverbs, i.e. a proverb minimum or optimum is therefore a desideratum. A proposal for English based on previous studies has been made here (see Appendix 1).

- The contrastive perspective should be considered in proverb teaching and learning because comparative studies help to find cross-linguistic differences. Since the learner's first language is a key factor in proverb processing and use in a foreign language, as a number of studies have found, proverb equivalents in L1 and L2 should be a special focus of instruction. 
- Autonomous learning is an integral part of proverb acquisition.

A final point is that the interest in phraseology and paremiology should not be restricted to practical language classes. Phraseology is an expanding area of research that has become an internationally recognized discipline in linguistics. As a subject at the intersection of lexicology and syntax with strong pragmatic and semantic implications it should also be taught as part of the linguistics program at universities, above all, in teacher training courses. Phraseology seminars can achieve a twofold aim: first, to introduce students to the most important theoretical concepts (defining criteria, classification, main approaches of research) and, second, to enlarge their individual stock of phraseological units including proverbs.

\section{References}

Abadi, M. (2000). Proverbs as ESL Curriculum. Proverbium 17, 1-22.

Awramiuk, E. (2011). Phraseology in Poles' language education. In J. Szerszunowicz, B. Nowowiejski, K. Yagi et al. (Eds.), Focal Issues of Phraseological Studies Volume I (pp. 371-387). Bialystok: University of Bialystok Publishing House

Bardósi, V., Ettinger, St. \& Stölting, C. (2003). Redewendungen Französisch-Deutsch (3. Aufl.). Tübingen/Basel: Francke.

Baur, R. S. \& Chlosta, Ch. (1996). Welche Übung macht den Meister? Von der Sprichwortforschung zur Sprichwortdidaktik. Fremdsprache Deutsch 2, 17-25.

Bergerová, H. (o.J./no year indicated). Multimediales Unterrichtsmaterial zur deutschen Phraseologie. http://frazeologie.ujepurkyne.com/index2.htm (accessed July 1, 2013).

Biber, D. \& Conrad, S. (1999). Lexical Bundles in Conversation and Academic Prose. In H. Hasselgard \& S. Oksefjell (Eds.), Out of Corpora. Studies in Honour of Stig Johansson (pp. 181-189). Amsterdam: Rodopi.

Collins Cobuild Idioms Dictionary (CCID). (2002). J. Sinclair et al. (Eds.) 2nd ed. Glasgow: HarperCollins.

Colson, J.-P. (2007). The World Wide Web as a corpus for set phrases. In H. Burger, D. Dobrovol'skij, P. Kühn \& N. R. Norrick (Eds.), Phraseologie. Phraseology. Ein internationals Handbuch zeitgenössischer Forschung. An International Handbook of Contemporary Research (pp. 1071-1077). Berlin/New York: de Gruyter.

Common European Framework of Reference for Languages: Learning, Teaching, Assessment. Ed. by Language Policy Division, Council of Europe, Strasbourg 2001, www.framework_en.pdf.

Conklin, C. \& Schmitt, N. (2008). Formulaic Sentences: Are the Processed More Quickly Than Nonformulaic Language by Native and Nonnative Speakers? Applied Linguistics 28, 1-18.

Cooper, Th. C. (1999). Processing of Idioms by L2 Learners of English. TESOL Quarterly 33/2, 233-262.

Cowie, A. (2003). Exploring native-speaker knowledge of phraseology: informant testing or corpus research. In H. Burger, A. Häcki-Buhofer \& G. Gréciano (Eds.), Flut von Texten - Vielfalt der Kulturen (pp. 73-81). Baltmannsweiler: Schneider-Verlag Hohengehren.

Crystal, D. (1998). Language Play. Harmondsworth: Penguin. 
Čermák, F. (2003). Paremiological minimum of Czech: The corpus evidence. In H. Burger, A. Häcki-Buhofer \& G. Gréciano (Eds.), Flut von Texten - Vielfalt von Kulturen (pp. 15-31). Baltmannsweiler: Schneider Verlag Hohengehren.

Čermák, F. (2004). Text introducers of proverbs and other idioms. In C. Földes \& J. Wirrer (Eds.), Phraseologismen als Gegenstand sprach- und kulturwissenschaftlicher Forschung (pp. 27-46). Baltmannsweiler: Schneider Verlag Hohengehren.

Dobrovol'skij, D. (2002): Phraseologismen in kontrastiver Sicht. In: D. A. Cruse, F. Hundsnurscher, M. Job et al. (Eds.), Lexikologie. Lexicology. Ein internationales Handbuch zur Natur und Struktur von Wörtern und Wortschätzen. An International Handbook on the Nature and Structure of Words and Vocabularies (pp. 442-451). Berlin/New York: de Gruyter.

Dobrovol'skij, D. (2011). Cross-Linguistic Equivalence of Idioms: Does it Really Exist? In A. Pamies \& D. Dobrovol'skij (Eds.), Linguo-Cultural Competence and Phraseological Motivation (pp. 7-24). Baltmannsweiler: Schneider.

Dobrovol'skij, D. \& Ljubimova, N. (1993). 'Wie man so schön sagt', kommt das gar nicht in die Tüte': Zur metakommunikativen Umrahmung von Idiomen. Deutsch als Fremdsprache 3, 151-156.

Ďurčo, P. (2004). Slovak Proverbial Minimum. In C. Földes (Ed.), Res Humanae Proverbiorum et Sententiarum. Ah honorem Wolfgangi Mieder (pp. 59-70). Tübingen: Gunter Narr.

Erman, B. \& Warren, B. (2000). The idiom principle and the open-choice principle. Text 20, 29-62.

Ettinger, St. (2001). Vom Lehrbuch zum autonomen Lernen. Skizze eines phraseologischen Grundkurses für Französisch. In M. Lorenz-Bourjot \& H. Lüger (Eds.), Phraseologie und Phraseodidaktik (pp. 87-104). Wien: Edition Praesens.

Ettinger, St. (2007). Phraseme im Fremdsprachenunterricht. In H. Burger, D. Dobrovol'skij, P. Kühn \& N. R. Norrick (Eds.), Phraseologie. Phraseology. Ein internationals Handbuch zeitgenössischer Forschung. An International Handbook of Contemporary Research (pp. 893-908). Berlin/New York: de Gruyter.

Farø, K. (2006). Idiomatizität - Ikonizität - Arbitrarität. Beitrag zu einer funktionalistischen Theorie der Idiomäquivalenz. (Dissertation) Copenhagen: University.

Fiedler, S. (2006). „Willkommen zurück!“ - der Einfluss des Englischen auf die Phraseologie der deutschen Gegenwartssprache. In H. Burger \& A. Häcki-Buhofer (Eds.), Phraseology in Motion I. Methoden und Kritik (pp. 451-465). Baltmannsweiler: Schneider-Verlag Hohengehren.

Fiedler, S. (2007). English Phraseology. A Coursebook. Tübingen: Gunter Narr.

Fiedler, S. (2010). „Am Ende des Tages zählt die Performance.“ - Der Einfluss des Englischen auf die Phraseologie der deutschen Gegenwartssprache. In J. Korhonen, W. Mieder, E. Piirainen et al. (Eds.), Phraseologie global - areal - regional. Akten der Konferenz EUROPHRAS $2008 \mathrm{vom}$ 13.-16.8.2008 in Helsinki (pp. 163-172). Tübingen: Gunter Narr.

Fiedler, S. (2012a). Englische Redewendungen und Sprichwörter in der Praxis. Leipzig: Engelsdorfer Verlag.

Fiedler, S. (2012b). Der Elefant im Raum ... The influence of English on German phraseology. In C. Furiassi, V. Pulcini \& F. Rodríguez González (Eds.), The Anglicization of European Lexis (pp. 239-259), Amsterdam/Philadelphia: Benjamins.

Gehweiler, E. (2006). "Going to the Dogs?" A Contrastive Analysis of sth. is going to the dogs and jmd./etw. geht vor die Hunde. International Journal of Lexicography 19/4, 419-438.

Gemeinsamer europäischer Referenzrahmen für Sprachen: Lernen, lehren, beurteilen. (2001). Berlin: Langenscheidt.

Gläser, R. (1990). Fachtextsorten im Englischen. Tübingen: Gunter Narr.

Gläser, R. (1986, ${ }^{21990) . ~ P h r a s e o l o g i e ~ d e r ~ e n g l i s c h e n ~ S p r a c h e . ~ L e i p z i g: ~ E n z y k l o p a ̈ d i e . ~}$

Granger, S. \& Meunier, F. (2008). Phraseology. An Interdisciplinary Perspective. Amsterdam: Benjamins. 
Grzybek, P. \& Chlosta, C. (2009). Some essentials on the popularity if (American) proverbs. In K. J. McKenna (Ed.), The Proverbial "Pied Piper". Festschrift Volume of Essays in Honor of Wolfgang Mieder on the Occasion of his Sixty-Fifth Birthday (pp. 95-110). New York: Peter Lang.

Günthner, S. (1990). Sprichwörtliche Redensarten in interkulturellen Kommunikationssituationen zwischen Deutschen und Chinesen. In B. Spillner (Ed.), Interkulturelle Kommunikation (pp. 53-61). Frankfurt am Main: Peter Lang.

Haas, H. A. (2008). Proverb familiarity in the United States: Cross-regional comparisons of the paremiological minimum. Journal of American Folklore 121/418, 319-347.

Hallsteinsdóttir, E. (2011). Aktuelle Forschungsfragen der deutschsprachigen Phraseodidaktik. Linguistik Online 47, 3, 1-25 (accessed July 1, 2013).

Hanzén, M. (2007). 'When in Rome, Do as the Romans Do'. Proverbs as a Part of EFL Teaching (Undergraduate Thesis Jönköping University, 33p.).

Howarth, P. (1998). Phraseology and second language proficiency. Applied Linguistics 19/1, 24-44.

Hessky, R. \& Ettinger, St. (1997). Deutsche Redewendungen. Ein Wörter- und Übungsbuch für Fortgeschrittene. Tübingen: Gunter Narr.

Irujo, S. (1986). Don't put your leg in your mouth: transfer in the acquisition of idioms in a second language. TESOL Quarterly 20, 287-304.

Irujo, S. (1993). Steering clear: Avoidance in the production of idioms. IRAL XXXI (3), 205-219.

Kacjan, B. (2013). Sprichwörter zwischen korpusbasierter Frequentanalyse und DaF-Wörterbüchern. In C. Konecny, E. Hallsteinsdóttir \& B.Kacjan (Eds.), Phraseologie und Sprachunterricht / Phraseology in Language Teaching and Language Didactics (pp. 71-88). Bielsko-Biała/ Budapest/Kansas et al.

Koller, W. (2004). Einführung in die Übersetzungswissenschaft. Wiesbaden: Quelle \& Meyer.

Konecny, C., Hallsteinsdóttir, E. \& Kacjan, B. (2013; in preparation). Zum Status quo der Phraseodidaktik: Aktuelle Forschungsfragen, Deiderata und Zukunftsperspektiven. In C. Konecny, E. Hallsteinsdóttir \& B. Kacjan (Eds.), Phraseologie und Sprachunterricht / Phraseology in Language Teaching and Language Didactics (pp. 153-172). Bielsko-Biała/ Budapest/Kansas et al.

Korhonen, J. (2007). Probleme der kontrastiven Phraseologie. In H. Burger, D. Dobrovol'skij, P. Kühn \& N. R. Norrick (Eds.), Phraseologie / Phraseology. Ein internatonales Handbuch zeitgenössischer Forschung. An International Handbook of Contemporary Research (pp. 574-589). Berlin/ New York: de Gruyter.

Kühn, P. (1992). Phraseodidaktik. Entwicklungen, Probleme und Überlegungen. Fremdsprachen Lehren und Lernen 21, 169-189.

Lakoff, G. \& Johnson, M. (1980). Metaphors We Live By. Chicago: University of Chicago Press.

Lattey, E. \& Hieke, A.E. (1990). Using Idioms in Situational Contexts. Tübingen: Francke.

Lau, K. J. (1996). 'It's about time': The ten proverbs most frequently used in newspapers and their relation to American values. Proverbium 13, 135-159.

Lenk, H. E. H. (2001). Von Felsmalereien und Hobbyethnologen. Die Phraseologie des Deutschrock als Gegenstand des DaF-Unterrichts. In M. Lorenz-Bourjot \& H. Lüger (Eds.), Phraseologie und Phraseodidaktik (pp. 155-178). Wien: Praesens.

Lennon, P. (1998). Approaches to the Teaching of Idiomatic English. IRAL, XXXVI (1), 11-30.

Litovkina, A.T. (2000). A Proverb A Day Keeps Boredom Away. Pécz-Szekszárd: IPF-Könyvek.

Lüger, H. (1997). Anregungen zur Phraseodidaktik. Beiträge zur Fremdsprachenvermittlung 32, 69-120.

Lüger, H. (2004). Idiomatische Kompetenz - ein realistisches Lernziel? Thesen zur Phraseodidaktik. Beiträge zur Fremdsprachenvermittlung Sonderheft 7, 121-169.

Mechling, J. (2004). "Cheaters Never Prosper" and Other Lies Adults Tell Kids: Proverbs and the Culture Wars over Character. In K. J. Lau, P. Tokofsky \& S. W. Winick (Eds.), What Goes Around, 
Comes Around. The Circulation of Proverbs in Contemporary Life (pp. 107-126). Logan, Utah: State University Press.

Mellado-Blanko, C. (2010). Die phraseologische Äquivalenz auf der System- und Textebene (am Beispiel des Sprachenpaares Deutsch-Spanisch). In J. Korhonen, W. Mieder \& Piirainen, E. (Eds.), Phraseologie global - areal - regional (pp. 277-284). Tübingen: Gunter Narr.

Meunier, F. \& Granger, S. (Eds.). Phraseology in Foreign Language Learning and Teaching. Amsterdam: Benjamins.

Mieder, W. (1989). Proverbs in popular songs. In W. Mieder (Ed.), American Proverbs: A Study of Texts and Contexts (pp. 195-212). Bern: Peter Lang.

Mieder, W. (1993). The only good Indian is a dead Indian: History and meaning of a proverbial stereotype. Journal of American Folklore 106, 38-60.

Mieder, W. (1994). Paremiological minimum and cultural literacy. In W. Mieder (Ed.), Wise Words. Essays on the Proverb (pp. 297-316). New York/London: Garland Publishing.

Mieder, W. (1996). Proverbs. In J. H. Brunvald (Ed.), American Folklore. An Encyclopedia (pp. 597-601). New York: Garland.

Mieder, W. (2004a). Der frühe Vogel und die goldene Morgenstunde. Zu einer deutschen Sprichwortentlehnung aus dem Angloamerikanischen. In I. Hyvärinen, P. Kallio \& J. Korhonen (Eds.), Etymologie, Entlehnungen und Entwicklungen. Festschrift für Jorma Koivulehto (pp. 193-206). Helsinki: Societé Néophilologique.

Mieder, W. (2004b). 'Man soll nicht alle Eier in einen Korb legen': Zur deutschsprachigen Entlehnung eines angloamerikanischen Sprichwortes. Nauchnyi vestnik. Seria Sovremennye lingvisticheskie i metodiko-didakticheskie issledovaniia 1, 21-31.

Mieder, W. (2004c). 'Ein Apfel pro Tag halt den Arzt fern': Zu einigen amerikanischen Lehnsprichwörtern im Deutschen. Revista de Filologia Alemana, 12 135-149.

Mieder, W. (2004d). Proverbs. A Handbook. Westport, Connecticut/London: Greenwood Press.

Mieder, W. (2005). "A proverb is worth a thousand words": Folk wisdom in the modern mass media. Proverbium 22, 167-233.

Mieder, W. (2007). Proverbs as cultural units or items of folklore. In H. Burger, D. Dobrovol'skij, P. Kühn \& N. R. Norrick (Eds.), Phraseologie. Phraseology. Ein internationals Handbuch zeitgenössischer Forschung. An International Handbook of Contemporary Research (pp. 394-414). Berlin/ New York: de Gruyter.

Mieder, W. (2010). 'Many roads lead to globalization'. The translation and distribution of AngloAmerican proverbs in Europe. In J. Korhonen, W. Mieder, E. Piirainen et al. (Eds.), Phraseologie global - areal - regional. Akten der Konferenz EUROPHRAS 2008 vom 13.-16.8.2008 in Helsinki (pp. 43-59). Tübingen: Gunter Narr.

Mieder, W., Kingsbury, S.A. \& Kelsie, B.H. (Eds.) (1992), A Dictionary of American Proverbs. Oxford: Oxford University Press.

Mieder, W. \& Litovkina, A. T. (2006). Old Proverbs Never Die, They Just Diversify. Veszprém: University Press Veszprém.

Moon, R. (1998). Fixed Expressions and Idioms in English. Oxford: Clarendon Press.

Naciscione, A. (2010). Stylistic Use of Phraseological Units in Discourse. Amsterdam: Benjamins. Norrick, N. R. (1985). How Proverbs Mean. Berlin: de Gruyter.

Nuessel, F. (1982). Incorporating proverbial language into the Spanish curriculum. The Canadian Modern Language Review 39, 83-89.

Nuessel, F. (2003). Proverbs and metaphoric language in second-language acquisition. In W. Mieder (Ed.) Cognition, Comprehension, and Communication. A Decade of North American Proverb Studies (1990-2000) (pp. 395-412). Baltmannsweiler: Verlag Hohengehren.

O'Keefe, A., McCarthy, M. \& Carter, R. (2007). From Corpus to Classroom: Language Use and Language Teaching. Cambridge: Cambridge University Press.

Paczolay, G. (1997). European Proverbs. Veszprém: Veszprémi Nyomda Rt. 
Partington, A.S. (2009). A linguistic account of wordplay. The lexical grammar of punning. Journal of Pragmatics 41, 1794-1809.

Pawley, A. \& Syder, F.H. (1983). Two puzzles for linguistic theory: nativelike selection and nativelike fluency. In J. C. Richards \& R. W. Schmidt (Eds.), Language and Communication (pp. 191-226). Harlow/London: Longman.

Permiakov, G. L. (1982). K voprosu o russkom paremiologicheskom minimum. In E. M. Vereshchagina (Ed.), Slovari I lingvostranovedenie (pp. 131-137). Moskva: Nauka.

Permiakov, G. L. (1985). 300 obshcheupotrebitel' nykh russkikh poslovits I pogovorok. Moskva: Nauka.

Piirainen, E. (2010). Common Features in the Phraseology of European Languages: Cultural and Areal Perspectives. In: J. Korhonen, W. Mieder, E. Piirainen et al. (Eds.), Phraseologie. Global - Areal - Regional (pp. 16-27). Tübingen: Gunter Narr.

Piirainen, E. (2012). Widespread Idioms in Europe and Beyond. Frankfurt am Main: Peter Lang.

Popovic, R. (2004). National Stereotypes in Teaching English as a Foreign Language (Master-Thesis). Brattleboro, Vermont.

Pirttisaari, P. (2006). Phraseologie im ‘Gemeinsamen europäischen Referenzrahmen für Sprachen'. In U. Breuer \& I. Hyvärinen (Eds.), Wörter-Verbindungen: Festschrift für Jarmi Korhonen (pp. 247-257). Frankfurt am Main: Peter Lang.

Prodromou, L. (2007). Bumping into creative idiomaticity. English Today 89 (23), No.1, 14-25.

Reershemius, G. (2012). Zur pragmatischen Funktion von Humor in wissenschaftlichen Vorträgen. Journal of Pragmatics 44, 863-875.

Rozumko, A. (2012). English influence on Polish proverbial language. In C. Furiassi, V. Pulcini \& F. Rodríguez González (Eds.), The Anglicization of European Lexis (pp. 261-277). Amsterdam/ Philadelphia: Benjamins.

Schmitt, N. (Ed.) (2004). Formulaic Sequences. Amsterdam: Benjamins.

Thielmann, W. (2009). Deutsche und englische Wissenschaftssprache im Vergleich: Hinführen Verknüpfen - Benennen. Heidelberg: Synchron Wissenschaftsverlag der Autoren.

Vajičková, M. (2000). Sprichwörter im Sprachvergleich unter fremdsprachendidaktischen Aspekten. In U. Kramer (Ed.), Lexikologisch-lexikographische Aspekte der deutschen Gegenwartssprache (pp. 157-165). Tübingen: Niemeyer.

Wilson, A. (2004). Good proverbs make good students. Using proverbs to teach German quickly. Proverbium 21, 345-370.

Winick, S.D. (2003). Intertextuality and innovation in the definition of the proverb genre. In W. Mieder (Ed.) Cognition, Comprehension, and Communication. A Decade of North American Proverb Studies (1990-2000) (pp. 371-599). Baltmannsweiler: Verlag Hohengehren.

Wotjak, B. (1996). Redewendungen und Sprichwörter. Ein Buch mit sieben Siegeln? Fremdsprache Deutsch 15, 4-9.

Wotjak, B. \& Richter, M. (1988). Sage und schreibe. Deutsche Phraseologismen in Theorie und Praxis. Leipzig: Enzyklopädie.

Wray, A. (2002). Formulaic Language and the Lexicon. Cambridge: Cambridge University Press. Wray, A. (2008). Formulaic Language: Pushing the Boundaries. Oxford: Oxford University Press. You, T. (2010). „Geteiltes Leid ist halbes Leid, geteilte Freude ist doppelte Freude“. In I.-A. Busch-Lauer (Ed.), Kaleidoskop der Kulturen (pp. 151-168). Berlin: Frank /Timme.

Wenger, E. (1998). Communities of Practice. Learning, Meaning, and Identity. Cambridge: Cambridge University Press. 


\section{Appendix 1}

Introduction: The 100 entries in this list are alphabetized according to the first noun in each proverb. If no noun occurs, the first autosemantic word is taken as a key word. The proverbs are arranged in the form of a table with reference to the sources mentioned in chapter 3.1 of this paper so that readers can make their own choices with regard to the criteria they find significant. For those who pay particular attention to the frequency of proverbs in a corpus, for example, items (14), (17) and (80) might be essential, although they are not listed in the classical collection by Lau (1996); for those who focus on the use of proverbs in the media will consider Lau's list to be the most important. The references in the last column indicate books in which examples of the particular proverbs in a modified version are given. The sources are some of Mieder's articles on proverbs in the media, Litovkina \& Mieder's collection of antiproverbs, and textbooks on phraseology by the author of this chapter. $C R$ stands for The Colbert Report, an American satirical TV program that is known for its playful use of proverbs.

15 proverbs (in bold letters) fulfil all the five selection criteria described in 3.1, and 55 four out of five. The field with the number in front of these 70 items has been highlighted in bold.

\begin{tabular}{|c|c|c|c|c|c|c|}
\hline & Proverb & $\begin{array}{l}\text { Mieder } \\
(2004)\end{array}$ & $\begin{array}{l}\text { Lau } \\
(1996)\end{array}$ & $\begin{array}{l}\text { Haas } \\
(2008)\end{array}$ & $\begin{array}{l}\text { CCID } \\
\text { (XX stands } \\
\text { for high } \\
\text { frequency) }\end{array}$ & Examples \\
\hline 1 & $\begin{array}{l}\text { Absence makes the } \\
\text { heart grow fonder }\end{array}$ & $X$ & 263 & $x$ & & $\begin{array}{l}\text { Litovkina/Mieder } \\
(2006: 81)\end{array}$ \\
\hline 2 & $\begin{array}{l}\text { Actions speak louder } \\
\text { than words }\end{array}$ & & 1970 & $x$ & $x$ & $\begin{array}{l}\text { Litovkina/Mieder } \\
\text { (2006: 83) }\end{array}$ \\
\hline 3 & $\begin{array}{l}\text { An apple a day keeps } \\
\text { the doctor away }\end{array}$ & $x$ & & $x$ & & $\begin{array}{l}\text { Fiedler } \\
\text { (2012: 75) }\end{array}$ \\
\hline 4 & $\begin{array}{l}\text { Beauty is in the eye of } \\
\text { the beholder }\end{array}$ & $x$ & & $x$ & & $\begin{array}{l}\text { Litovkina/Mieder } \\
\text { (2006: 100) }\end{array}$ \\
\hline 5 & $\begin{array}{l}\text { Beauty is only skin- } \\
\text { deep. }\end{array}$ & $x$ & & $x$ & & $\begin{array}{l}\text { Mieder } \\
(2005: 218)\end{array}$ \\
\hline 6 & $\begin{array}{l}\text { Early to bed and early } \\
\text { to rise, makes a man } \\
\text { healthy, wealthy, and } \\
\text { wise }\end{array}$ & $X$ & 35 & $x$ & & $\begin{array}{l}\text { Mieder } \\
\text { (2004d: 178) }\end{array}$ \\
\hline 7 & $\begin{array}{l}\text { Beggars can't be choos- } \\
\text { ers }\end{array}$ & $x$ & 33 & $x$ & $x$ & $\begin{array}{l}\text { Litovkina/Mieder } \\
(2006: 102 / 103)\end{array}$ \\
\hline 8 & $\begin{array}{l}\text { A bird in the hand is } \\
\text { worth two in the bush }\end{array}$ & $x$ & 201 & $x$ & $x$ & $\begin{array}{l}\text { Fiedler } \\
(2007: 85)\end{array}$ \\
\hline
\end{tabular}




\begin{tabular}{|c|c|c|c|c|c|c|}
\hline 9 & $\begin{array}{l}\text { Birds of a feather flock } \\
\text { together }\end{array}$ & $\mathrm{x}$ & 267 & $x$ & $\mathrm{x}$ & $\begin{array}{l}\text { Fiedler } \\
(2012: 40)\end{array}$ \\
\hline 10 & $\begin{array}{l}\text { The early bird catches } \\
\text { the worm }\end{array}$ & $x$ & 91 & $x$ & $x$ & $\begin{array}{l}\text { Fiedler } \\
(2012: 48)\end{array}$ \\
\hline 11 & $\begin{array}{l}\text { Blood is thicker than } \\
\text { water }\end{array}$ & & 410 & $x$ & $\mathrm{x}$ & $\begin{array}{l}\text { Mieder } \\
\text { (2004d: 253) }\end{array}$ \\
\hline 12 & $\begin{array}{l}\text { Don't judge a book by } \\
\text { its cover }\end{array}$ & $\mathrm{x}$ & & $x$ & $\mathrm{x}$ & $\begin{array}{l}\text { Mieder } \\
(2005: 203)\end{array}$ \\
\hline 13 & $\begin{array}{l}\text { If it ain't broke, don't } \\
\text { fix it }\end{array}$ & & & & $x x$ & $\begin{array}{l}\text { (CR 25 June } \\
2012)\end{array}$ \\
\hline 14 & $\begin{array}{l}\text { New brooms sweep } \\
\text { clean }\end{array}$ & $\mathrm{x}$ & 125 & $x$ & $x$ & $\begin{array}{l}\text { Mieder } \\
(2005: 223)\end{array}$ \\
\hline 15 & $\begin{array}{l}\text { Business before plea- } \\
\text { sure }\end{array}$ & $\mathrm{x}$ & 91 & $x$ & & $\begin{array}{l}\text { Litovkina/Mieder } \\
(2006: 111)\end{array}$ \\
\hline 16 & $\begin{array}{l}\text { You cannot have your } \\
\text { cake and eat it too }\end{array}$ & $\mathrm{x}$ & & $x$ & $x x$ & $\begin{array}{l}\text { Fiedler } \\
\text { (2007: 83) }\end{array}$ \\
\hline 17 & $\begin{array}{l}\text { When the cat's away, the } \\
\text { mice will play }\end{array}$ & & & $x$ & $x$ & $\begin{array}{l}\text { Mieder } \\
(2005: 184)\end{array}$ \\
\hline 18 & Charity begins at home & & 1163 & $x$ & $x$ & $\begin{array}{l}\text { Fiedler } \\
(2007: 112)\end{array}$ \\
\hline 19 & $\begin{array}{l}\text { Chickens come home to } \\
\text { roost }\end{array}$ & $x$ & 585 & $x$ & & $\begin{array}{l}\text { Fiedler } \\
(2007: 79)\end{array}$ \\
\hline 20 & $\begin{array}{l}\text { Don't count your } \\
\text { chickens before they are } \\
\text { hatched }\end{array}$ & $x$ & & $x$ & $x$ & $\begin{array}{l}\text { Litovkina/Mieder } \\
\text { (2006: } 127)\end{array}$ \\
\hline 21 & $\begin{array}{l}\text { Every cloud has a silver } \\
\text { lining }\end{array}$ & $x$ & 425 & $x$ & $x$ & $\begin{array}{l}\text { Fiedler } \\
\text { (2007: 94) }\end{array}$ \\
\hline 22 & Easy come, easy go & $x$ & 1220 & $x$ & $x$ & $\begin{array}{l}\text { Fiedler } \\
(2007: 108)\end{array}$ \\
\hline 23 & First come, first served & $x$ & 13,050 & $x$ & & $\begin{array}{l}\text { Litovkina/Mieder } \\
(2006: 148)\end{array}$ \\
\hline 24 & $\begin{array}{l}\text { Two's company and } \\
\text { three is a crowd }\end{array}$ & & 93 & $x$ & & $\begin{array}{l}\text { Fiedler } \\
\text { (2007: 92) }\end{array}$ \\
\hline 25 & $\begin{array}{l}\text { Too many cooks spoil } \\
\text { the broth }\end{array}$ & $x$ & 173 & $x$ & $x$ & $\begin{array}{l}\text { Litovkina/Mieder } \\
\text { (2006: } 313 / 314)\end{array}$ \\
\hline 26 & Curiosity killed the cat & $x$ & & $x$ & $x$ & $\begin{array}{l}\text { Mieder } \\
\text { (2004d: 240) }\end{array}$ \\
\hline 27 & Every dog has its day & & 550 & $x$ & $x$ & $\begin{array}{l}\text { Litovkina/Mieder } \\
(2006: 140)\end{array}$ \\
\hline 28 & Let sleeping dogs lie & $x$ & & $x$ & $\mathrm{x}$ & $\begin{array}{l}\text { Litovkina/Mieder } \\
(2006: 198)\end{array}$ \\
\hline 29 & $\begin{array}{l}\text { You can't teach an old } \\
\text { dog new tricks }\end{array}$ & $x$ & & $x$ & $x$ & $\begin{array}{l}\text { Litovkina/Mieder } \\
(2006: 347)\end{array}$ \\
\hline
\end{tabular}




\begin{tabular}{|c|c|c|c|c|c|c|}
\hline 30 & $\begin{array}{l}\text { Don't put all your eggs } \\
\text { in one basket }\end{array}$ & $\mathrm{X}$ & & $x$ & $x$ & $\begin{array}{l}\text { Litovkina/Mieder } \\
(2006: 131)\end{array}$ \\
\hline 31 & All's well that ends well & $x$ & 879 & $x$ & & $\begin{array}{l}\text { Litovkina/Mieder } \\
(2006: 90)\end{array}$ \\
\hline 32 & $\begin{array}{l}\text { The end justifies the } \\
\text { means }\end{array}$ & & 1,882 & $x$ & & $\begin{array}{l}\text { Litovkina/Mieder } \\
\text { (2006: 281/282) }\end{array}$ \\
\hline 33 & $\begin{array}{l}\text { The exception proves } \\
\text { the rule }\end{array}$ & & 912 & $x$ & $x$ & $\begin{array}{l}\text { Litovkina/Mieder } \\
(2006: 282)\end{array}$ \\
\hline 34 & Like father, like son & $x$ & 1,593 & $x$ & & $\begin{array}{l}\text { Litovkina/Mieder } \\
(2006: 203)\end{array}$ \\
\hline 35 & $\begin{array}{l}\text { Fine feathers make fine } \\
\text { birds }\end{array}$ & & 7 & $x$ & & $\begin{array}{l}\text { Litovkina/Mieder } \\
\text { (2006: 148) }\end{array}$ \\
\hline 36 & $\begin{array}{l}\text { A fool and his money are } \\
\text { soon parted }\end{array}$ & $X$ & 79 & $x$ & $x$ & $\begin{array}{l}\text { Litovkina/Mieder } \\
(2006: 61)\end{array}$ \\
\hline 37 & Forewarned is forearmed & & 520 & $x$ & $x$ & $\begin{array}{l}\text { Forewarned is } \\
\text { Disarmed (Song- } \\
\text { text Napalm } \\
\text { Death); Fore- } \\
\text { warned is Not } \\
\text { Forwarned (Title } \\
\text { of an essay by A. } \\
\text { Huxley 1931) }\end{array}$ \\
\hline 38 & $\begin{array}{l}\text { A friend in need is a } \\
\text { friend indeed }\end{array}$ & $x$ & & $x$ & & $\begin{array}{l}\text { Litovkina/Mieder } \\
(2006: 64)\end{array}$ \\
\hline 39 & Garbage in, garbage out & & & & $x$ & $\begin{array}{l}\text { Mieder } \\
(2005: 212)\end{array}$ \\
\hline 40 & $\begin{array}{l}\text { Don't look a gift horse in } \\
\text { the mouth }\end{array}$ & $x$ & & $x$ & $x$ & $\begin{array}{l}\text { Mieder } \\
\text { (2004d: 243) }\end{array}$ \\
\hline 41 & $\begin{array}{l}\text { All that glitters is not } \\
\text { gold }\end{array}$ & $x$ & 251 & $x$ & & $\begin{array}{l}\text { Fiedler } \\
(2012: 22)\end{array}$ \\
\hline 42 & $\begin{array}{l}\text { The grass is always } \\
\text { greener on the other } \\
\text { side of the fence }\end{array}$ & $x$ & & $x$ & $x$ & $\begin{array}{l}\text { Fiedler } \\
(2012: 37)\end{array}$ \\
\hline 43 & $\begin{array}{l}\text { Many hands make light } \\
\text { work }\end{array}$ & $x$ & 62 & $x$ & & $\begin{array}{l}\text { Litovkina/Mieder } \\
(2006: 214)\end{array}$ \\
\hline 44 & $\begin{array}{l}\text { Make hay while the sun } \\
\text { shines }\end{array}$ & $x$ & & $x$ & $x$ & $\begin{array}{l}\text { Fiedler } \\
(2007: 91) \\
\end{array}$ \\
\hline 45 & $\begin{array}{l}\text { Handsome is as hand- } \\
\text { some does }\end{array}$ & & 85 & $x$ & $x$ & $\begin{array}{l}\text { Litovkina/Mieder } \\
(2006: 159)\end{array}$ \\
\hline 46 & Haste makes waste & $x$ & & $x$ & & $\begin{array}{l}\text { Litovkina/Mieder } \\
(2006: 160)\end{array}$ \\
\hline 47 & $\begin{array}{l}\text { Two heads are better } \\
\text { than one }\end{array}$ & $X$ & & $x$ & & $\begin{array}{l}\text { Fiedler } \\
(2007: 82)\end{array}$ \\
\hline
\end{tabular}




\begin{tabular}{|c|c|c|c|c|c|c|}
\hline 48 & $\begin{array}{l}\text { If you can't stand the } \\
\text { heat, get out of the } \\
\text { kitchen }\end{array}$ & & & $x$ & $X$ & $\begin{array}{l}\text { Mieder } \\
(2005: 206)\end{array}$ \\
\hline 49 & He who hesitates is lost & $x$ & & $x$ & & $\begin{array}{l}\text { Litovkina/Mieder } \\
\text { (2006: 162) }\end{array}$ \\
\hline 50 & History repeats itself & & 3,713 & $\mathrm{x}$ & & $\begin{array}{l}\text { Litovkina/Mieder } \\
(2006: 160)\end{array}$ \\
\hline 51 & $\begin{array}{l}\text { Honesty is the best } \\
\text { policy }\end{array}$ & $x$ & 714 & $x$ & & $\begin{array}{l}\text { Mieder } \\
(2005: 226)\end{array}$ \\
\hline 52 & $\begin{array}{l}\text { You can lead a horse } \\
\text { to water, but you can't } \\
\text { make him drink }\end{array}$ & $x$ & & $\mathrm{x}$ & $x$ & $\begin{array}{l}\text { Fiedler } \\
(2012: 57)\end{array}$ \\
\hline 53 & $\begin{array}{l}\text { Strike while the iron } \\
\text { is hot }\end{array}$ & $x$ & & $x$ & $X$ & $\begin{array}{l}\text { Litovkina/Mieder } \\
(2006: 272)\end{array}$ \\
\hline 54 & $\begin{array}{l}\text { It isn't over until the fat } \\
\text { lady sings }\end{array}$ & & & $\mathrm{x}$ & $x$ & $\begin{array}{l}\text { VP Gore, it's } \\
\text { over! The fat lady } \\
\text { is fixen to sing! } \\
\text { Herald Tribune } \\
\text { (14 Dec } 2000, \\
\text { on the Florida } \\
\text { recount) }\end{array}$ \\
\hline 55 & Better late than never & $x$ & 3,493 & $x$ & & $\begin{array}{l}\text { Litovkina/Mieder } \\
(2006: 106)\end{array}$ \\
\hline 56 & $\begin{array}{l}\text { A leopard does not } \\
\text { change its spots }\end{array}$ & & & $x$ & $x$ & $\begin{array}{l}\text { Litovkina/Mieder } \\
(2006: 287)\end{array}$ \\
\hline 57 & $\begin{array}{l}\text { He who laughs last, } \\
\text { laughs best }\end{array}$ & $x$ & & $x$ & $x$ & $\begin{array}{l}\text { Mieder } \\
(2005: 218)\end{array}$ \\
\hline 58 & Live and let live & $\mathrm{x}$ & 1,949 & $\mathrm{x}$ & & $\begin{array}{l}\text { Litovkina/Mieder } \\
\text { (2006: 204) }\end{array}$ \\
\hline 59 & $\begin{array}{l}\text { A drowning man will } \\
\text { clutch at a straw }\end{array}$ & & 3 & $x$ & $\mathrm{x}$ & $\begin{array}{l}\text { Litovkina/Mieder } \\
(2006: 61)\end{array}$ \\
\hline 60 & $\begin{array}{l}\text { One man's meat is } \\
\text { another man's poison }\end{array}$ & & & $x$ & $x$ & $\begin{array}{l}\text { Mieder } \\
(2004: 245)\end{array}$ \\
\hline 61 & Misery loves company & $x$ & 858 & $x$ & & $\begin{array}{l}\text { Litovkina/Mieder } \\
\text { (2006: 219) }\end{array}$ \\
\hline 62 & Money talks & $x$ & & $x$ & $x$ & $\begin{array}{l}\text { Litovkina/Mieder } \\
\text { (2006: 227) }\end{array}$ \\
\hline 63 & $\begin{array}{l}\text { The pen is mightier than } \\
\text { the sword }\end{array}$ & & & $x$ & & $\begin{array}{l}\text { Mieder } \\
(2005: 187)\end{array}$ \\
\hline 64 & $\begin{array}{l}\text { A penny saved is a } \\
\text { penny earned }\end{array}$ & $x$ & 264 & $x$ & & $\begin{array}{l}\text { Mieder ( } \\
\text { 2004: 248) }\end{array}$ \\
\hline
\end{tabular}




\begin{tabular}{|c|c|c|c|c|c|c|}
\hline 65 & $\begin{array}{l}\text { In for a penny, in for a } \\
\text { pound }\end{array}$ & & 92 & $x$ & $x$ & $\begin{array}{l}\text { In for a Penny, In } \\
\text { for } \$ 2.98 \text { Trillion } \\
\text { (Huffington Post } \\
1 \text { Apr 2009) }\end{array}$ \\
\hline 66 & $\begin{array}{l}\text { People who live in glass } \\
\text { houses should not throw } \\
\text { stones }\end{array}$ & & 37 & $x$ & $\mathrm{x}$ & $C R$ (14 Feb 2012) \\
\hline 67 & No news is good news & & & $x$ & $x$ & $\begin{array}{l}\text { Litovkina/Mieder } \\
\text { (2006: 238) }\end{array}$ \\
\hline 68 & $\begin{array}{l}\text { An ounce of prevention } \\
\text { is worth a pound of cure }\end{array}$ & $x$ & 668 & $x$ & & $\begin{array}{l}\text { Litovkina/Mieder } \\
(2006: 96)\end{array}$ \\
\hline 69 & $\begin{array}{l}\text { A watched pot never } \\
\text { boils }\end{array}$ & $\mathrm{X}$ & & $x$ & $\mathrm{x}$ & $\begin{array}{l}\text { Litovkina/Mieder } \\
(2006: 78)\end{array}$ \\
\hline 70 & $\begin{array}{l}\text { The pot calls the kettle } \\
\text { black }\end{array}$ & & 39 & $x$ & $x$ & $C R$ (16 Apr 2012) \\
\hline 71 & Practice makes perfect & $\mathrm{X}$ & 1,406 & $x$ & & $\begin{array}{l}\text { Litovkina/Mieder } \\
(2006: 262)\end{array}$ \\
\hline 72 & $\begin{array}{l}\text { Practise what you } \\
\text { preach }\end{array}$ & & & $x$ & $x$ & $\begin{array}{l}\text { Litovkina/Mieder } \\
(2006: 262)\end{array}$ \\
\hline 73 & Pride goes before a fall & & 34 & $x$ & & $\begin{array}{l}C R \\
(25 \text { March 2013) }\end{array}$ \\
\hline 74 & $\begin{array}{l}\text { The proof of the pudding } \\
\text { is in the eating }\end{array}$ & & 352 & $x$ & $x$ & $\begin{array}{l}\text { Litovkina/Mieder } \\
\text { (2006: 292) }\end{array}$ \\
\hline 75 & $\begin{array}{l}\text { It never rains, but it } \\
\text { pours / When it rains, } \\
\text { it pours }\end{array}$ & $x$ & 147 & $x$ & $\mathrm{X}$ & $\begin{array}{l}\text { Fiedler } \\
(2012: 71)\end{array}$ \\
\hline 76 & $\begin{array}{l}\text { When in Rome, do as the } \\
\text { Romans do }\end{array}$ & $x$ & 383 & $x$ & & $\begin{array}{l}\text { Fiedler } \\
\text { (2012: 49) }\end{array}$ \\
\hline 77 & $\begin{array}{l}\text { Rome was not built in } \\
\text { a day }\end{array}$ & & 122 & $x$ & $x$ & $\begin{array}{l}\text { Litovkina/Mieder } \\
(2006: 265)\end{array}$ \\
\hline 78 & Easier said than done & $x$ & & $x$ & $x X$ & $\begin{array}{l}\text { Litovkina/Mieder } \\
(2006: 136)\end{array}$ \\
\hline 79 & $\begin{array}{l}\text { What's sauce for the } \\
\text { goose is sauce for the } \\
\text { gander }\end{array}$ & & 613 & $x$ & $\mathrm{x}$ & $\begin{array}{l}C R \\
(28 \text { March 2013) }\end{array}$ \\
\hline 80 & Seeing is believing & & 1,767 & $x$ & & $\begin{array}{l}\text { Litovkina/Mieder } \\
\text { (2006: 268) }\end{array}$ \\
\hline 81 & $\begin{array}{l}\text { If the shoe /cap fits, } \\
\text { wear it }\end{array}$ & $x$ & & $x$ & $x$ & $\begin{array}{l}\text { Litovkina/Mieder } \\
(2006: 176)\end{array}$ \\
\hline 82 & Out of sight, out of mind & $x$ & 2,902 & $x$ & $x$ & $\begin{array}{l}\text { Litovkina/Mieder } \\
(2006: 256)\end{array}$ \\
\hline 83 & $\begin{array}{l}\text { There's many a slip } \\
\text { between the cup and } \\
\text { the lip }\end{array}$ & & 45 & $x$ & $x$ & $\begin{array}{l}\text { Litovkina/Mieder } \\
(2006: 300)\end{array}$ \\
\hline
\end{tabular}




\begin{tabular}{|c|c|c|c|c|c|c|}
\hline 84 & $\begin{array}{l}\text { Where there's smoke, } \\
\text { there's fire }\end{array}$ & $x$ & 429 & $x$ & $\mathrm{x}$ & $\begin{array}{l}\text { Mieder } \\
(2005: 169)\end{array}$ \\
\hline 85 & $\begin{array}{l}\text { Speech is silver, silence } \\
\text { is golden }\end{array}$ & & 930 & $x$ & & $\begin{array}{l}\text { Litovkina/Mieder } \\
\text { (2006: 271) }\end{array}$ \\
\hline 86 & $\begin{array}{l}\text { A stitch in time saves } \\
\text { nine }\end{array}$ & $x$ & 122 & $x$ & $x$ & $\begin{array}{l}\text { Litovkina/Mieder } \\
(2006: 77)\end{array}$ \\
\hline 87 & $\begin{array}{l}\text { A rolling stone gathers } \\
\text { no moss }\end{array}$ & $x$ & 51 & $x$ & $x$ & $\begin{array}{l}\text { Mieder } \\
(2005: 173)\end{array}$ \\
\hline 88 & $\begin{array}{l}\text { That' the last straw (that } \\
\text { breaks the camel's back) }\end{array}$ & & & & $x$ & $\begin{array}{l}\text { Litovkina/Mieder } \\
\text { (2006: 286) }\end{array}$ \\
\hline 89 & $\begin{array}{l}\text { One swallow doesn't } \\
\text { make a summer }\end{array}$ & & 146 & $x$ & $x$ & $\begin{array}{l}\text { Litovkina/Mieder } \\
\text { (2006: } 252 \text { ) }\end{array}$ \\
\hline 90 & It takes two to tango & $x$ & & $x$ & $x$ & $\begin{array}{l}\text { Litovkina/Mieder } \\
(2006: 187)\end{array}$ \\
\hline 91 & Time is money & $x$ & 3,770 & $x$ & & $\begin{array}{l}C R \\
\text { (14 March 2012) }\end{array}$ \\
\hline 92 & Time will tell & & 14,226 & $x$ & & $\begin{array}{l}\text { Mieder/Litovkina } \\
(2006: 309 / 310)\end{array}$ \\
\hline 93 & $\begin{array}{l}\text { Never put off till tomor- } \\
\text { row what you can do } \\
\text { today }\end{array}$ & $x$ & & $x$ & & $\begin{array}{l}\text { Litovkina/Mieder } \\
\text { (2006: 234) }\end{array}$ \\
\hline 94 & $\begin{array}{l}\text { Variety is the spice of } \\
\text { life }\end{array}$ & & 390 & $x$ & $x$ & $\begin{array}{l}\text { Mieder } \\
(2005: 193)\end{array}$ \\
\hline 95 & Waste not, want not & $x$ & & $x$ & & $\begin{array}{l}\text { Mieder } \\
(2005: 220)\end{array}$ \\
\hline 96 & Still waters run deep & $x$ & 135 & $x$ & $\mathrm{x}$ & $\begin{array}{l}\text { Litovkina/Mieder } \\
(2006: 272)\end{array}$ \\
\hline 97 & $\begin{array}{l}\text { There's more than one } \\
\text { way to skin a cat }\end{array}$ & & 18 & $x$ & $x$ & $\begin{array}{l}\text { Litovkina/Mieder } \\
\text { (2006: 296) }\end{array}$ \\
\hline 98 & $\begin{array}{l}\text { Where there's a will, } \\
\text { there's a way }\end{array}$ & & 1,015 & $x$ & $x$ & $\begin{array}{l}\text { Mieder } \\
(2004: 239)\end{array}$ \\
\hline 99 & $\begin{array}{l}\text { All work and no play } \\
\text { makes Jack a dull boy }\end{array}$ & & & $x$ & & $\begin{array}{l}\text { Fiedler } \\
(2007: 75 / 76)\end{array}$ \\
\hline 100 & $\begin{array}{l}\text { Two wrongs don't make } \\
\text { a right }\end{array}$ & $x$ & & $x$ & & $\begin{array}{l}\text { Litovkina/Mieder } \\
\text { (2006: } 321)\end{array}$ \\
\hline
\end{tabular}




\section{Appendix 2}

Examples of non-verbally presented proverbs and of proverbs embedded in context (The pictures were found in Mieder [2005: 191; 187])

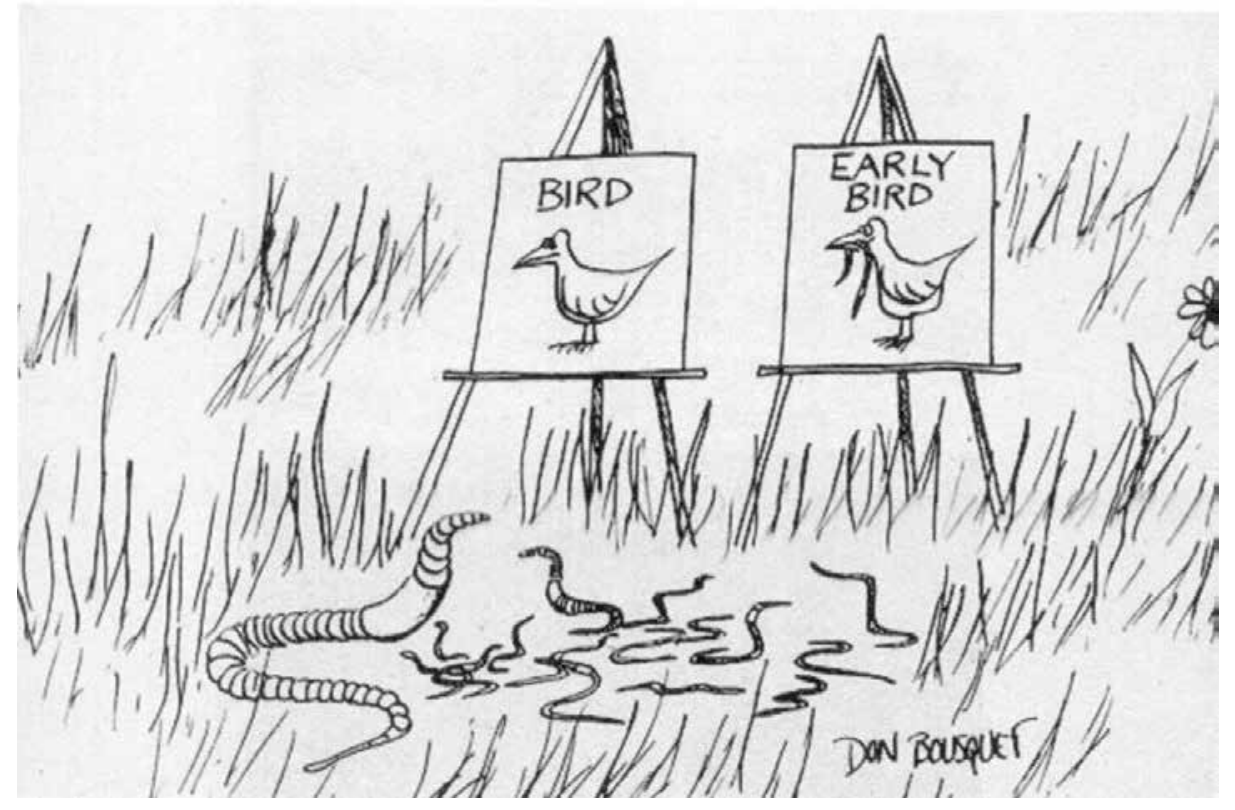




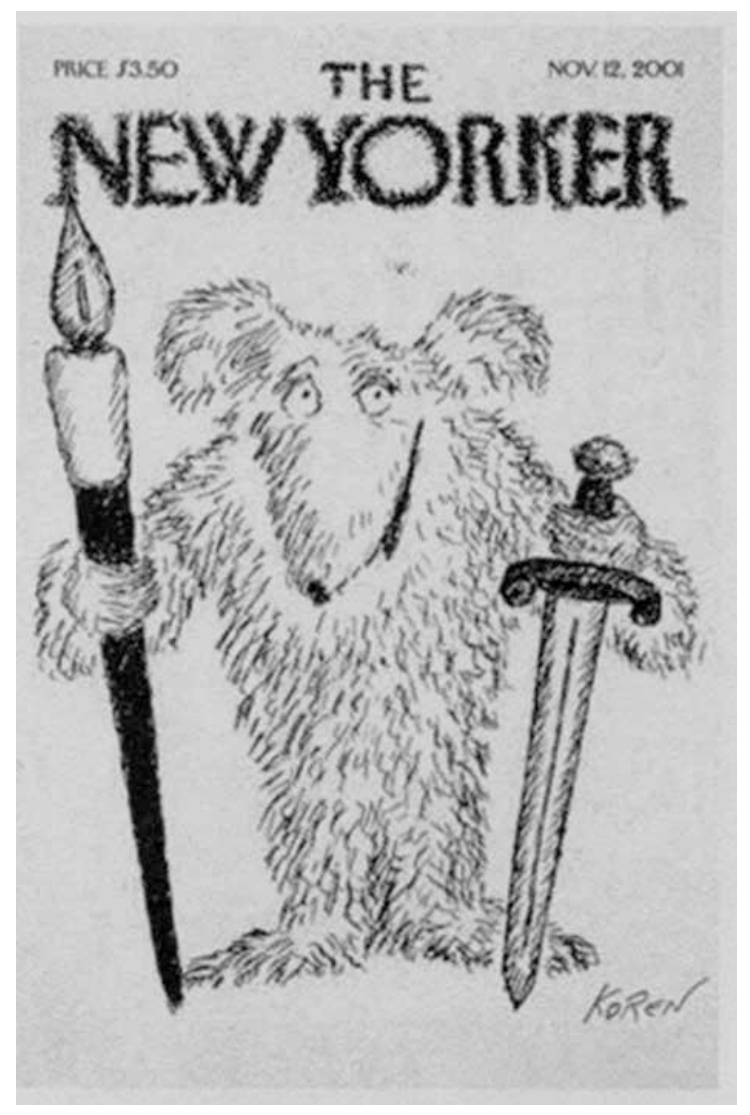

[...] He sent his troops into Chechnya in 1999 after a series of explosions in Russia that the authorities blamed on Chechen rebels. - ehm - However, throughout this crisis he had not even discussed this prime demand of the Chechen hostage takers that Russia would draw out its forces from Chechnya. [...] Putin himself has been portraying this operation or this Chechen take-over in Moscow as part of the world-wide terror activities. So in the short term perhaps - ehm -ehm - a climb in popularity for Wladimir Putin, but what this incident has done is to focus attention on the situation in Chechnya and on the fact that after years of having said that he is dealing with it the problem remains and came home to roost in the very middle of Moscow to me. (spoken report: CNN, November 2, 2002) 


\section{The Pen Is Mightier Than the Sword}

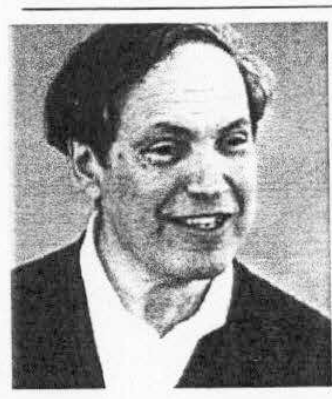

Area professors unite and create proposals to quell brutality in its many forms

(Dec. 2, 2004) GENEVA, N.Y.--The professors gathered from Finger Lakes area colleges have dubbed themselves Group of Seven. Should they achieve their goal--reducing violence in America--they may become known as "The Magnificent Seven."

Started by Marvin Bram, professor emeritus of history and Hobart and William Smith Colleges, Group of Seven can be thought of as a combination think tank and book club, only without the books. In their stead are seven papers, drafts of which are written by individual members, that concentrate on remedies for violence. The group plans to meet and discuss one draft a month, with everyone giving feedback to improve the recommendations therein. The first meeting is scheduled for Thursday, Dec. 9. 